\title{
Evaluation of Policies on Aceh Qanun Regulation
}

\author{
Said Mayzar Mulia ${ }^{1}$ Ismail $^{2}$ \\ 1Universitas Merdeka Malang, Indonesia \\ ${ }^{2}$ Universitas Iskandar Muda, Banda Aceh, Indonesia \\ Email: sayed.mayzar@gmail.com
}

\begin{abstract}
:
In Aceh development activities are basically carried out actively, arief and wise including in applying a regional policy in the form of Circular (SE) Number 450/21770 which contains about the prohibition of holding recitation other than I'tiqad Ahlussunnah Waljamaah which is sourced from the Shafi'ite School law well, around last December 2019 that made a commotion in the public in Aceh. This causes great concern for the community regarding the clash of the Circular with article 14 paragraph (3) of the Aceh Qanun Number 8 of 2014 which regulates the Principles of Islamic Sharia stating that the holding of worship which does not refer not to the Syafi'i sect is permitted. Given as long as within the framework of the Hanafi, Maliki and Hambali mazhas by always promoting harmony, ukhuwah Islamiah and peace within the Muslim community, even though hierarchically the Circular Letter (SE) legislation is lower than Qanun, which is likely to use political means as a driving force for local government.

\section{Keywords:}

evaluation of Aceh Qanun Policies and Regulations
\end{abstract}

\section{Introduction}

In developing of the understanding of regional government Qanun, the government should be observant, thorough and systematic towards the policies issued to avoid the divisions in the life of civil society in Aceh. This consequence, as stated in the Circular Letter 450/21770 Regional Head, must not conflict with the provisions contained in the Qanun as a higher regulation. Of course, the issuance of Circular Letter which overlaps with Aceh Qanun Number 8 of 2014, has several consequences from a juridical and social consequence. For this reason, this paper attempts to elaborate on the polemic of policy conflicts in Aceh Qanun regulation, which actually violates the rules of law, which adhere to the principle of lex superior derogat legi inferior law, where lower laws must be in accordance with the provisions above them. , in order to maintain synchronization between one condition with another.

In 2019, to be exact in December or the month of 2019, Aceh was once again in the spotlight of the people with Circular Letter of Number 450/21770 concerning the prohibition of holding religious studies other than I'tiqad Ahlussunnah Waljamaah, which originated from Shafi'ite School of Law. Suddenly Circular Letter (SE) issued on Friday, December 13, 2019, provoked various reactions from various circles. One of the concerns is the contents of Circular Letter (SE) Number 450/21770 which collides with the provisions contained in Aceh Qanun Number 8 of 2014 concerning the Principles of Islamic Sharia, by emphasizing as article 1 number 15 states "Islamic Sharia is a guide and the rule of Islamic law in all aspects of life ". Thus, Shari'a which allows it to be held in accordance with the circular referred to is not permitted to recite other than Shafi'i School.

Likewise, the emphasis of article 14 paragraph (3) Aceh Qanun of Number 8 of 2014 which regulates the Principles of Islamic Sharia states that the holding of worship which does not refer not to t Syafi'i schools is permissible while within the Hanafi, Maliki and Hambali 
school of thought. It always prioritize harmony, ukhuwah Islamiah and peace within the Muslim community. In fact, in a hierarchical circular, the Circular Letter is lower than Qanun, which is likely to use political facilities as a motor of regional government.

Whereas if referred to the juridical aspect, it violates the rules in the science of legislation, which adheres to the principle of lex superior derogat legi inferior law, in the sense that Circular Letter (SE) as a lower provision overlaps with Qanun Number 8 of 2014 as a rule higher. Indirectly, the move of the Aceh Government to issue Circular Letter has damaged the hierarchy of statutory regulations as regulated in Law Number 12 of 2011 concerning Formation of Laws and Regulations, which are reiterated in Qanun Number 5 of 2011 concerning The Procedure for Making Qanun.

The long journey focuses on a pluralistic life with cultural diversity, but the implementation of Shari'ah can be carried out by all occupiers of the Muslim earth as article 1 number 24 states that "Shari'a is all activities that contain and support the values of worship to enlighten and state that implementation of Islamic teachings".

\section{Review of Literature}

Understanding the substance of Qanun evaluation number 8 of 2014 concerning the Principles of Islamic Sharia is caused by conflicts that may be deliberate and unintentional in the national political arena in accordance with the interests of political actors. Basically the emphasis on the implementation of Islamic law in Aceh covers all aspects of community life and apparatuses in Aceh whose implementation includes Aqeedah, Syar'iyah, and morality which has been regulated in Aceh Qanun Number 8 of 2014 concerning Principles of Islamic Sharia. One of the points of discussion contained therein and later returned to conversation is about khilafiyah in terms of organizing worship.

In Chapter VI on Shari'ah, Part One which contains the matters of Worship, Article 14, there are several points that explain the related issues, which are as follows:

1. The implementation of worship in Aceh must be carried out in accordance with Islamic guidance.

2. The implementation of worship as regulated in paragraph (1) is practiced by prioritizing the procedures for practicing worship according to Shafi'i school.

3. The implementation of worship that does not refer to Shafi'i school of worship is permitted as long as within the framework of Hanafi, Maliki and Hambali schools by always promoting harmony, ukhuwah Islamiyah and peace among Muslims.

4. In the case that there are community groups in Aceh who have practiced Hanafi school of thought, Maliki or Hambali cannot be forced to practice Shafi'i school.

5. In the case that community groups who practice worship follow the understanding of religious organizations that are in accordance with the Koran and Hadith and are legally recognized by the State, it remains justified/ protected.

6. With regard to contemporary problems found in the fourth school, further study can be carried out by the Aceh MPU involving relevant institutions.

7. If there is kbilafiah in the organization of worship, muqakarah or a comprehensive study will be carried out by the Aceh MPU which involves relevant institutions by prioritizing the spirit of ukbuwah Islam, tolerance (tasamub) and openness.

8. Aceh Government and Regency/City Government are obliged to provide facilities and create conditions and a conducive environment for the implementation of worship.

9. Every government agency, company, private institution and public facility provider must 
provide appropriate worship facilities.

10. The Aceh MPU is obliged to oversee worship that deviates from sharia rules which has the potential to cause unrest and conflict in society.

11.Further provisions regarding worship are regulated in the Aceh Qanun.

\section{Research Methods}

\section{Description of Circular Letter Number 450/21770}

Translation of Circular Letter Number 450/21770 issued on December 13, 2019, signed by the Acting Governor of Aceh Nova Iriansyah and addressed to the regents/ mayors, SKPA, and Kakanwil Ministry/Non-Ministry in Aceh Province, contains a Prohibition of Conducting Studies Other Than I'tiqad Ablussunnah Waljamaah which is sourced from Syafi'yah School of Law.

Actually, the ban is an effort to follow up Law Number 44 Year 1999 concerning the implementation of special features of the Aceh Special Province. Law number 11 of 2006 concerning the Government of Aceh qanun number 2 of 2009 concerning Ulama Consultative Assembly, Aceh Qanun number 8 of 2014 concerning the principles of Islamic Sharia and Aceh Qanun number 8 of 2015 concerning Development and Protection of Aqidah.

When examined closely after the issuance of the Circular (SE), it also refers to the Aceh Qanun Number 01 of 2019 concerning the Aceh Medium-Term Development Plan for 2017-2022, with the mission of strengthening the implementation of Islamic Sharia along with Islamic values and the culture of deity in people's lives with I'tiqad Ablussunnah Waljamaah who comes from Syafi'iyah School of Law while respecting other schools of thought.

Obviously there is a problem here as if there is an element of compelling the parties when they look deeper and / or in plain observation in the mental and spiritual development of the Islamic Acehnese society, but in general do not have the intention to damage the Islamic record that has been built since the rule of the empire in long time ago.

After evaluating the documented essence of the SE, contained in points 3 and 4, which read: "To maintain the religious atmosphere of the Acehnese people in worship, and so as not to develop I'tiqad/ flow/ school other than Ablussunnah Waljamaah and Syafi'yah School of Law "We forbid the holding of studies/ studies other than I'tiqad Ablussunnab Waljamaab and other than Syafi'iyah School and the organizers to consult with the Aceh MPU as well as SKPA Heads and Regents/ Mayors to always supervise, evaluate and record data again according to names of lecturers/ lecturers in each institution.

\section{Discussion}

In the science of law, there is a theory of hierarchy. Hierarchy theory is a theory which states that the legal system is arranged in stages and stratified like a rung. The relationship between norms that govern the actions of other norms and other norms is referred to as super relations and subordination in a spatial context. Norms that determine the actions of other norms are superior, whereas norms that do actions are called inferior norms. Therefore, actions carried out by higher norms (superior) become the reason for the validity of the whole legal system that forms a single unit. 
In Indonesia, this chain of legal norms is actualized into a hierarchy of statutory regulations as regulated in Law Number 12 of 2011 concerning Formation of Laws and Regulations (Law No. 12 of 2011). Article 7 paragraph (1) of Law No. 12 of 2011 mentions the types and hierarchy of laws and regulations in Indonesia, namely:

1. The 1945 Constitution of the Republic of Indonesia;

2. Decree of the People's Consultative Assembly;

3. Government Act / Regulation in Lieu of Law;

4. Government Regulations;

5. Presidential Regulation;

6. Provincial Regulations;

7. Regency / City Regional Regulations.

In terms of authority, the hierarchy of laws and regulations also applies to Qanun, as a Sharia Regional Regulation (Perda) in Aceh. In the Aceh administration, the division of government affairs related to Islamic sharia between the Aceh Government and district / city government is regulated by the Aceh Qanun. Although there is no standard definition regarding Sharia Law, but if you see Article 7 paragraph (1) of Law 12 of 2011, the Sharia Law is ranked 6/7 from the above mentioned hierarchy, namely Provincial Regional Regulation or Regency / Regional Regulation A city whose contents regulate religious affairs.

All policies that should have been made and made do not occur in conflict with the higher rules above, in this case Aceh Qanun. This is because, the hierarchy of laws and regulations is lower than Qanun, besides the issuance of Circular (SE) is also based on or part of the follow-up of the existing rules. It would be formally juridical wrong if the contents of the Circular (SE) overlap with the higher regulation (superior) as a reason for the validity of the whole legal system that forms a single unit.

Last December 2019, the issuance of Circular Letter (SE) Number 450/21770 which was signed by the Acting Governor of Aceh, provoked various parties who questioned the position of Circular Letter (SE) which in the hierarchy of laws and regulations was lower than Qanun. Circular Letter (SE) Number 450/21770 that talks about the prohibition of holding recitals other than I'tiqad Ahlussunnah Waljamaah sourced from the Aceh Government's Syafi'yah School of Law, substantively contradicting existing legal provisions, namely the Aceh Qanun Number 8 of 2014 about the Principles of Islamic Sharia.

In the Circular Letter (SE) Number 450/21770, on the third and fourth points, the government clearly prohibited the holding of religious studies other than I'tiqad Ahlussunnah Waljamaah and Syafi'i School, whereas in Aceh Qanun Number 8 of 2014 concerning Sharia Principles Islam, article 14 verses 3, 4 and 5 expressly regulates the permissibility of worship by other schools other than the Shafi'i school. Paragraph 3 stipulates that "The conduct of worship that does not refer to the Shafi'i school of worship is permissible as long as within the framework of the Hanafi, Maliki and Hambali schools by always promoting harmony, ukhuwah Islamiyah and tranquility among Muslims." Whereas Paragraph 4 regulates, "In the case that there are groups of people in Aceh who have practiced the Hanafi school of thought, Maliki or Hambali cannot be forced to practice the Shafi'i school. Then it is strengthened by paragraph (5) which explains, "In the case of groups of people who practice worship following the understanding of religious organizations in accordance with the Koran and Hadith and recognized legally by the State it remains justified/ protected." 
The emergence of Circular Letter (SE) Number 450/21770, overrides the provisions of the points mentioned in Qanun Number 8 of 2014. This actually weakens the position of Circular Letter (SE) Number 450/21770, because it has violated the rules in the science of legislation, which adheres to the principle of the law of lex superior derogat legi inferior, that is higher legislation will paralyze the laws and regulations lower, or in other words the lower level law must be in accordance with the provisions above. To maintain synchronization between one provision and another, the application of the principle of lex superior derogat legi inferiori has become a fundamental requirement. However, here it looks the science of law, there is a theory of hierarchy. Hierarchy theory is a theory which states that the legal system is arranged in stages and stratified like a rung. The relationship between norms that govern the actions of other norms and other norms is referred to as super relations and subordination in a spatial context. Norms that determine the actions of other norms are superior, whereas norms that do actions are called inferior norms. Therefore, actions carried out by higher norms (superior) become the reason for the validity of the whole legal system that forms a single unit.

In Indonesia, this chain of legal norms is actualized into a hierarchy of statutory regulations as regulated in Law Number 12 of 2011 concerning Formation of Laws and Regulations (Law No. 12 of 2011). Article 7 paragraph (1) of Law No. 12 of 2011 mentions the types and hierarchy of laws and regulations in Indonesia, namely:

1. The 1945 Constitution of the Republic of Indonesia;

2. Decree of the People's Consultative Assembly;

3. Government Act / Regulation in Lieu of Law;

4. Government Regulations;

5. Presidential Regulation;

6. Provincial Regulations;

7. Regency / City Regional Regulations.

In terms of authority, the hierarchy of laws and regulations also applies to Qanun, as a Sharia Regional Regulation (Perda) in Aceh. In the Aceh administration, the division of government affairs related to Islamic sharia between the Aceh Government and district / city government is regulated by the Aceh Qanun. Although there is no standard definition regarding Sharia Law, but if you see Article 7 paragraph (1) of Law 12 of 2011, the Sharia Law is ranked 6/7 from the above mentioned hierarchy, namely Provincial Regional Regulation or Regency / Regional Regulation A city whose contents regulate religious affairs.

All policies that should have been made and made do not occur in conflict with the higher rules above, in this case the Aceh Qanun. This is because, the hierarchy of laws and regulations is lower than the Qanun, besides the issuance of Circular (SE) is also based on or part of the follow-up of the existing rules. It would be formally juridical wrong if the contents of the Circular overlap with the higher regulation (superior) as a reason for the validity of the whole legal system that forms a single unit.

Last December 2019, the issuance of Circular Letter (SE) Number 450/21770 which was signed by the Acting Governor of Aceh, provoked various parties who questioned the position of Circular Letter which in the hierarchy of laws and regulations was lower than the Qanun. Circular Letter Number 450/21770 that talks about the prohibition of holding recitals other than I'tiqad Ahlussunnah Waljamaah sourced from the Aceh Government's Syafi'yah School of Law, substantively contradicting existing legal provisions, namely Aceh Qanun Number 8 of 2014 about the Principles of Islamic Sharia. 
In the Circular Letter Number 450/21770, on the third and fourth points, the government clearly prohibited the holding of religious studies other than I'tiqad Ahlussunnah Waljamaah and Syafi'i School, whereas in Aceh Qanun Number 8 of 2014 concerning Sharia Principles Islam, article 14 verses 3, 4 and 5 expressly regulates the permissibility of worship by other schools other than the Shafi'i school. Paragraph 3 stipulates that "The conduct of worship that does not refer to Shafi'i school of worship is permissible as long as within the framework of the Hanafi, Maliki and Hambali schools by always promoting harmony, ukhuwah Islamiyah and tranquility among Muslims." Whereas Paragraph 4 regulates, "In the case that there are groups of people in Aceh who have practiced the Hanafi school of thought, Maliki or Hambali cannot be forced to practice Shafi'i school. Then it is strengthened by paragraph (5) which explains, "In the case of groups of people who practice worship following the understanding of religious organizations in accordance with the Koran and Hadith and recognized legally by the State it remains justified / protected."

The emergence of Circular Letter Number 450/21770, overrides the provisions of the points mentioned in Qanun Number 8 of 2014. This actually weakens the position of Circular Letter (SE) Number 450/21770, because it has violated the rules in the science of legislation, which adheres to the principle of the law of lex superior derogat legi inferior, that is higher legislation will paralyze the laws and regulations lower, or in other words the lower level law must be in accordance with the provisions above. To maintain synchronization between one provision and another, the application of the principle of lex superior derogat legi inferiori has become a fundamental requirement. However, it is seen here that the legal principle of lex superior derogat inferior legi is not a consideration for the issuance of Circular Letter Number 450/21770. So it is out of sync with the provisions in Qanun Number 8 of 2014.

In fact, the points in Circular Letter Number 450/21770 also contradict each other. There is an element of inconsistency in it. Starting from the first point that mentions the intent of the letter as a follow up to some related rules, one of which is Aceh Qanun Number 8 of 2014, which clearly overlaps with the call in a circular. Then, in point 2, which refers to Aceh Qanun Number 01 Year 2019 regarding the Aceh Medium Term Development Plan (RPJM) for 2017-2022, related to the mission of strengthening the implementation of Islamic Sharia along with Islamic values and the culture of peace in the lives of the people with 'itigad Ablussunnab Waljamaah which originates from Syafi'iyah School of Law while respecting other schools of thought. The RPJM firmly instructs respect for different schools, as a form of building a culture of tolerance in society. However, in point 3, it reads "To maintain the religious atmosphere of the Acehnese people in worship, and so that the development of I'tiqad/flow/school of thought other than Ablussunnah Waljamaah and Shafi'i School." Substantially, by Nasrun Zaman, it is considered that the contents of the Circular are not consistent between the first point and the next point, at one point explaining the permissibility/respect of other schools but on the next point there is a prohibition on other schools besides Syafi'iyah mahab, which are shown are the contents of a Circular from the Governor of Aceh in contrast to the Aceh RPJM which upholds the development of a culture of tolerance.

By some parties, the presence of Circular Letter (SE) Number 450/21770 is feared to trigger intolerant attitudes and actions in the community. As happened some time ago, at the Oman al-Makmur Mosque in Banda Aceh, where riots by a group of people stopped the study of Ust. Farhan is considered not Ablussunnah Waljamaah and adherents of Shafi'i School. In this case, when viewed in terms of causality, Circular Letter (SE) by the Acting Governor Number 450/21770 is addressed to regents/mayors, SKPA, and Ministries / Non-Ministries 
Regional Offices in Aceh Province, considered as causa remota (farthest cause) from noise that occurred at the Oman Mosque. Although the Circular is normative (not a priori binding, only regulating), not imperative (a priori binding), but it can influence the minds of the people who are interpreted outside of juridical studies. As a result, this Circular can be used as a justification for community groups to be intolerant.

Further developments from various circles, Acting Governor Circular Letter Number $450 / 21770$ are judged to be legally flawed. Because it clashes with the provisions in a hierarchical manner, the contents of Circular Letter (SE) Number 450/21770 are substantively contrary to the law above, namely the Aceh Qanun Number 8 of 2014 concerning the Principles of Islamic Sharia. This juridical defect if seen legally includes the criteria for nietigheid van rechtswege (null and void) because of legal conflicts that are hierarchically higher in position. Therefore, here is actually the position and validity of the SE is not legally strong, especially with the existence of the principle of lex superior derogat legi inferior, ie higher legislation will cripple lower legislation.

That way, the material content contained in the Circular may not exceed the material that has been contained in the regulations above that already exist. If there is a conflict with the above regulation, then the position of this Circular Letter must be open to be ruled out by a higher degree hierarchy.

\section{Conclusion}

Circular issued by the government, in the rule of law, has a lower position than Qanun. The consequence is that the provisions contained therein must not violate and contradict the provisions contained in Qanun. If it contradicts, the issuance of the Circular violates the principle of lex superior derogat legi inferior law, with which there is a juridical defect with the criteria of nietigheid van rechtswege (null and void) due to conflict with the higher hierarchical law. This is true for Circular Letter Number 450/21770 which substantively contradicts the law above, namely Aceh Qanun Number 8 of 2014 concerning the Principles of Islamic Sharia. The existence of Aceh Qanun Number 8 of 2014 has legally weakened the position of Circular Letter (SE) Number 450/21770, and can be considered nietigheid van rechtswege (null and void).

\section{References}

Asshiddiqie, Jimly and Safa'at, M. Ali. 2006. Theory Hans Kelsen Tentang Hukum. Jakarta: Sekretariat Jenderal dan Kepaniteraan Mahkamah Konstitusi RI.

Maria Farida Indrati. 1998. Ilmu Perundang-Undangan: Dasar dan Cara Pembentukannya. Yogjakarta: Kanisius.

Firma, Aditya Zaka and Winata, Reza M.. 2018. Rekonstruksi Hierarki Peraturan PerundangUndangan di Indonesia. Jurnal Negara Hukum.

Pasal 13 ayat (1) Undang-Undang (UU) Nomor 11 Tahun 2006.

Pasal 1 angka 21 dan angka 22 UU 11/2006.

Sudikno Mertokusumo. 1986. Mengenal Hukum (Suatu Pengantar). Yogyakarta: Liberty.

Pengamat Kebijakan Publik Aceh. Pandangannya ini terangkum dalam Aceh Journal National Network (AJNN). Lihat dalam https://www.ajnn.net/news/pengamat-kebijakan-publik-suratedaran-gubernur-tak-sesuai-qanun/index.html is accessed at 07th February 2020. 